\title{
PENGGUNAAN KALIMAT EFEKTIF DALAM PIDATO TEKS KENEGARAAN JOKOWI
}

\section{USE OF EFFECTIVE SENTENCES IN THE TEXT OF JOKOWI'S STATE SPEECH}

\author{
Ikhwanudin Abdillah; Zulkifli; Sabhan \\ Program Studi Pendidikan Bahasa dan Sastra Indonesia \\ FKIP Universitas Lambung Mangkurat \\ abdillahikhwanudin@gmail.com
}

\begin{abstract}
Abstrak
Kalimat Efektif merupakan kalimat yang benar dan jelas sesuai dengan kaidah bahasa Indonesia. Pidato merupakan seni berbicara secara monolog yang terbagi kedalam beberapa jenis dengan memperhatikan skema atau pola yang membangunnya. Tujuan dari penelitian ini untuk mendeskripsikan penggunaan kalimat efektif dalam pidato kenegaraan Jokowi. Pendekatan yang dipakai pada penelitian ini adalah kualitatif dengan menggunakan metode deskriptif. Penelitian ini mengacu pada teks pidato kenegaraan Jokowi sebagai sumber data. Hasil penelitian ini menunjukkan penggunaan kalimat efektif sangat berpengaruh terhadap berbagai hal yang berkaitan dengan karya tulis seperti teks pidato kenegaraan Jokowi. Penggunaan kalimat efektif dalam teks pidato kenegaraan Jokowi terdiri dari beberapa ciri meliputi gramatikal yang mana disetiap pidato banyak terdapat kesalahan seperti dalam pembuatan paragraf, PUEBI terutama dalam penggunaan tanda baca, jelasnya suatu kalimat didalam teks pidato, ringkasnya suatu kalimat didalam teks pidato, saling berhubungannya satu kalimat dengan kalimat yang lain, bervariasinya pemilihan kata didalam teks pidato, dan tidak adanya unsur yang tidak berfungsi didalam kalimat.
\end{abstract}

Kata Kunci: kalimat efektif, teks pidato kenegaraan jokowi

\begin{abstract}
Effective Sentences are true and clear sentences in accordance with Indonesian rules. Speech is the art of speaking in a monologue that is divided into several types by paying attention to the scheme or pattern that builds it. The purpose of this study is to describe the use of effective sentences in Jokowi's state speech. The approach used in this study is qualitative using descriptive methods. The data source in this study is the text of Jokowi's state speech. The results of this study indicate that the use of effective sentences is very influential on various matters relating to written works such as the text of Jokowi's state speech. The use of effective sentences in Jokowi's state speech text consists of several characteristics including grammatical which in each speech there are many errors such as in making paragraphs, PUEBI especially in the use of punctuation, clear a sentence in speech text, summarizing a sentence in a speech text, interconnected sentences with other sentences, varying selection of words in the speech text, and the absence of elements that do not function in the sentence.
\end{abstract}

Keywords: effective sentence, the text of Jokowi's state speech 


\section{Pendahuluan}

Bahasa merupakan perwujudan suatu budaya di masyarakat. Bahasa memegang peranan penting sebagai sarana komunikasi dalam kehidupan bermasyarakat. Keraf (1978:14) menyebutkan bahwa bahasa sebagai alat untuk mengadakan hubungan dan komunikasi dengan anggota-anggota masyarakat. Ditinjau dari pernyataan yang dibuat oleh Gorys Keraf, tentu mendukung fungsi bahasa sebagai alat komunikasi untuk mengadakan hubungan antarmasyarakat. Dengan bahasa, sarana komunikasi menjadi hidup dan berfungsi sebagai penyampai suatu informasi. Informasi tidak dapat dilepaskan dari proses komunikasi. Proses komunikasi selalu melibatkan komunikator sebagai penyampai informasi dan komunikan sebagai penerimanya.

Peristiwa komunikasi dapat kita jumpai dalam kehidupan sehari-hari. Peristiwa tersebut dapat terjadi pada berbagai situasi, situasi formal dan nonformal. Selain itu, penyampaian komunikasi juga dapat ditentukan oleh bentuk komunikasi yang digunakan. Misalnya, dalam komunikasi formal, bentuk yang digunakan adalah komunikasi satu arah (monologika). Komunikasi satu arah adalah bentuk komunikasi yang hanya satu orang menjadi pembicara atau komunikator, sedangkan yang lain menjadi pendengar. Bentuk utama monologika atau komunikasi satu arah ini adalah pidato.

Pidato adalah seni berbicara secara monolog yang terbagi ke dalam beberapa jenis dengan memerhatikan skema atau pola yang membangunnya. Proses atau peristiwa penyampaian informasi oleh komunikator kepada komunikan dalam pidato tentu memerlukan keterampilan dalam menggunakan bahasa sebagai alat komunikasi agar informasi dapat disampaikan dengan baik dan benar.

Keterampilan berbahasa saat berpidato tercermin pada setiap ujaran yang disampaikan oleh komunikator. Pidato adalah bentuk monologika (komunikasi satu arah) yang mana tidak ada kesempatan bagi komunikan untuk bertanya terkait hal yang tidak dipahami dari isi pidato yang disampaikan komunikator hingga pidato selesai. Oleh karena itu, dalam berpidato harus menggunakan kalimat efektif agar informasi yang diberikan dapat dipahami oleh komunikan.

Semi (2009:218--219) menyatakan bahwa suatu kalimat dikatakan efektif apabila mengandung ciri-ciri berikut ini. (1) Gramatikal, ditinjau dari aspek tata bahasa sesuai dengan kaidah bahasa Indonesia. (2) Sesuai dengan tuntutan bahasa baku, menggunakan ejaan yang 
tepat dan menggunakan bahasa baku sesuai tata bahasa. (3) Jelas, kalimat itu dipahami. (4) Ringkas dan lugas serta tidak berbelit-belit. (5) Adanya hubungan yang baik (koherensi) antara satu kalimat dengan kalimat yang lain, antara satu paragraf dengan paragraf yang lain. (6) Kalimat harus hidup atau bervariasi dalam hal pilihan kata, urutan kata dalam kalimat, bentuk kalimat, gaya bahasa, perumpamaan dan perbandingan, dan panjang pendeknya kalimat.(7) Tidak ada unsur yang tidak berfungsi dalam kalimat.

Pengaplikasian kalimat efektif dalam berpidato menjadi tantangan bagi komunikator yang harus dihadapi agar maksud yang hendak disampaikan dapat dikemas dan diserap oleh pendengar dengan baik. Banyak kita jumpai, fenomena gagal paham atau informasi yang tidak tersampaikan dengan baik saat berpidato disebabkan tuturan yang kurang jelas ataupun ada kata yang tidak dimengerti oleh pendengar. Umumnya, hal ini terjadi pada masyarakat awam yang kurang mengetahui beberapa arti atau makna kata yang disampaikan oleh komunikator.

Dalam kasus ini, pidato kenegaraan atau pidato resmi negara adalah contoh peristiwa komunikasi yang melibatkan semua lapisan masyarakat sebagai pendengar. Baik menjadi pendengar langsung maupun melalui media.
Komunikan yang beragam, yang terdiri dari semua lapisan masyarakat, menjadi tantangan dalam bermonologika. Pidato yang melibatkan beragam pendengar seperti pidato Presiden pertama RI di Bandung saat Konferensi Asia Afrika pada 18-24 April 1955, pidato Bung Karno yang berjudul "To Build The World a New" pada Sidang Umum PBB tahun 1960, dan "New Emerging Forces" pada KTT Non Blok tahun 1961 di Beograd, Serbia.

Presiden, selaku komunikator yang pidatonya didengar oleh seluruh rakyat, harus cermat dalam memilih kata dan memadukan setiap kalimat yang diujarkan. Pasalnya, tidak semua masyarakat dapat dikatagorikan sebagai pendengar yang mempunyai wawasan sama. Sebagian orang berpendapat bahwa pidato yang disampaikan oleh Presiden sudah tentu efektif dan dapat diterima oleh pendengar. Namun, tidak semua individu paham dengan maksud kalimat efektif. Dengan teori yang sudah ada, perlu pembuktian secara ilmiah terhadap isi pidato presiden agar dapat diketahui keefektifan kalimat yang digunakan dalam pidato, Penelitian yang sama pernah dilakukan Alfiyan (2016) dengan judul "Tindak Tutur Dalam Teks Pidato Presiden Ir.H. Jokowidodo", dan Ariyani 2016 dengan judul “Topikalisasi dalam Pidato Kenegaraan Presiden Jokowi Periode Agustus 2015 dan Rancangannya terhadap 
Pembelajaran Bahasa Indonesia di SMA". Berdasarkan uraian tersebut, peneliti berminat untuk mengkaji penggunaan kalimat efektif pada pidato kenegaraan, sehingga peneliti bermaksud untuk meneliti beberapa teks pidato Presiden RI untuk dikaji dengan mengangkat judul penelitian "Penggunaan Kalimat Efektif dalam Teks Pidato Kenegaraan Jokowi

\section{Metode Penelitian}

Pendekatan yang digunakan adalah pendekatan kualitatif dengan menggunakan metode deskriptif. Tujuan dari penelitian deskriprif ini untuk menggambarkan atau melukiskan keadaan di lapangan secara sistematis dengan faktafakta dan penafsiran yang tepat, selain itu juga membuat data-data saling berhubungan, serta dengan tujuan mencari pemahaman observasi.

Data penelitian ini berupa kalimat efektif yang berkaitan dengan gramatikal, PUEBI, jelas, ringkas, koherensi, bervariasi, tidak sesuai. Data penelitian tersebut bersumber pada teks pidato kenegaraan Jokowi yang terdiri sebanyak tiga teks.

Penelitian ini menggunakan teknik studi pustaka, yaitu teknik pemerolehan data melalui sumber tertulis. Seperti pidato, peneliti menggunakan teknik studi pustaka dengan membaca dan mengidentifikasi pidato-pidato kenegaraan
Presiden Jokowi sebagai sumber data, kemudian peneliti mencatat bagian-bagian dari sumber data yang sesuai dengan permasalahan mengenai kalimat efektif di dalam pidato-pidato kenegaraan Presiden Jokowi.

Setelah data-data terkumpul, langkah selanjutnya adalah menganalisis data-data tersebut. Teknik analisis data yang digunakan peneliti adalah penggunaan kaidah bahasa, dengan fokus utama penggunaan kalimat efektif. Teknik ini dilakukan setelah data terkumpul kemudian menganalisis kalimat efektif di dalam pidato-pidato kenegaraan Presiden Jokowi. Adapun langkah-langkah yang dilakukan sebagai berikut.

a) Membaca dan memahami kalimat efektif.

b) Membaca dan memahami pidatopidato kenegaraan Presiden Jokowi.

c) Mengidentifikasi permasalahan yang ada di dalam pidato-pidato kenegaraan Presiden Jokowi.

d) Menyimpulkan hasil penelitian bagaimana penggunaan kalimat efektif di dalam pidato-pidato kenegaraan Presiden Jokowi.

\section{Hasil Penelitian dan Pembahasan Pidato Kenegaraan Jokowi I}

Berdasarkan data yang ditemukan di dalam naskah pidato Jokowi terdapat penggunaan kalimat yang tidak efektif, 
antara lain meliputi gramatikal, PUEBI, ringkas, dan bervariasi.

Gramatikal

Pertama, kesalahan yang dapat dikategorikan menyangkut gramatikal yang terkait dengan paragraf. Sebuah paragraf yang benar jika sebuah paragraf terdiri lebih dari satu kalimat.

Kutipan terdapat pada Pidato Jokowi I. menunjukkan paragraf yang tidak tepat.

Kini, setelah 73 tahun merdeka, kita harus melanjutkan elan semangat para pejuang kemerdekaan itu untuk bekerja nyata mengisi kemerdekaan, untuk bekerja nyata memenuhi janji-janji kemerdekaan, dan untuk bekerja nyata mewujudkan keadilan sosial bagi seluruh rakyat Indonesia.

(satu paragraf tidak boleh terdiri dari satu kalimat)

Kedua, muncul pula dalam penggunaan kata sambung. Selain penempatan kata sambung, terdapat pernyataan yang menyatakan bahwa terdapat kata sambung yang sejajar, seperti pasangan kata tidak dan tetapi.

Ketiga, kesalahan penulisan bentuk jamak. Beberapa unsur tidak perlu ditulis dengan perulangan, cukup ditulis bentuk dasarnya saja. Berikut kesalahan penulisan bentuk jamak yang dijumpai dalam teks pidato 1 .

Keempat, kesalahan penulisan kata asing yang digunakan dalam teks pidato 1 .
Setiap kata asing yang belum diserap harus ditulis miring atau garis bawah (apabila teks itu ditulis dengan gaya miring secara keseluruhan).

Dengan hasil itu, Negara kita sudah masuk ke kategori High Human Development.

(kata asing seharusnya bercetak miring atau tebal)

Kelima, kesalahan penulisan imbuhan. Imbuhan yang dimaksud adalah imbuhan awal yaitu se-. Penulisan imbuhan tersebut harus ditulis serangkai dengan kata yang mengikutinya.

Keenam, kesalahan penggunaan tanda baca. Dalam pidato 1 terdapat beberapa kekeliruan dalam menempatkan tanda baca.

a. PUEBI

Pedoman Umum Ejaan Bahasa Indonesia atau PUEBI merupakan sebuah kaidah bahasa Indonesia. Adapun kesalahan yang ditemukan dalam naskah pidato Jokowi 1 meliputi:

pertama, beberapa kata dijumpai tidak menggunakan kata dan kaidah baku. Kedua, pemilihan diksi yang kurang tepat. Sesuai KBBI, kata memiliki definisi tertentu sehingga perlu kecermatan dalam memilih diksi yang digunakan.

b. Jelas, mudah untuk dipahami.

Sebuah kalimat atau paragraf harus memiliki kejelasan atau dapat diterima nalar berpikir. Teks pidato 1 memuat 
beberapa kalimat atau paragraf yang kurang jelas karena beberapa hal. Hal yang dimaksud ialah kekeliruan memungsikan sebuah kalimat, menggolongkan kalimat aktif atau pasif, perujukan, menghubungkan kalimat induk dengan anaknya, dan lain sebagainya.

\section{c. Ringkas}

Sebuah kalimat dinyatakan efektif jika hemat dalam pemakaiannya. Kalimat yang hemat akan memudahkan komunikan menerima informasi yang disampaikan. Dalam teks pidato 1, terdapat beberapa kalimat yang tidak hemat sehingga membuat penerima informasi kesulitan untuk menangkap maksud penyampai informasi.

Yang saya hormati, seluruh rakyat

Indonesia, dari Sabang sampai

Merauke, dari Miangas sampai

Pulau Rote;

(terlalu banyak menggunakan kata dari)

d. Koherensi

Sebuah teks harus memiliki kepaduan antarkalimat atau antarparagraf sehingga dapat dikatakan efektif. Pada teks pidato 1 dijumpai ketidak paduan antarparagraf. Hal ini terlihat dari gagasan yang mendasarinya.

e. Bervariasi

Dalam pidato 1, terdapat kalimat yang tidak bervariasi dalam hal pemilihan kata sebagai berikut.
Solidaritas, peduli, dan berbagi antarsesama saudara, satu bangsa, satu bahasa, dan satu tanah air.

(kurangnya dalam variasi kata karena terlalu banyak menggunakan kata satu).

\section{Pidato Kenegaraan Jokowi II}

Berdasarkan data yang ditemukan di dalam naskah pidato Jokowi terdapat penggunaan kalimat yang tidak efektif , antara lain meliputi gramatikal, PUEBI, ringkas, dan tidak sesuai.

a) Gramatikal

Pertama, kesalahan yang dapat dikategorikan menyangkut gramatikal yang terkait dengan paragraf. Sebuah paragraf yang benar jika sebuah paragraf terdiri lebih dari satu kalimat.Kutipan Pidato Jokowi 2 menunjukkan paragraf yang tidak tepat.

Kedua, muncul pula dalam penggunaan kata sambung. Selain penempatan kata sambung, terdapat pernyataan yang menyatakan bahwa terdapat kata sambung yang sejajar, seperti pasangan kata tidak dan tetapi.

Ketiga, kesalahan penulisan imbuhan. Imbuhan yang dimaksud adalah imbuhan awal yaitu se-. Penulisan imbuhan tersebut harus ditulis serangkai dengan kata yang mengikutinya. Keempat, kesalahan penggunaan tanda baca. Dalam pidato 1 terdapat beberapa kekeliruan dalam menempatkan tanda baca.

b) PUEBI 
Adapun kesalahan yang ditemukan dalam naskah pidato Jokowi 2 meliputi: pertama, beberapa kata dijumpai tidak menggunakan kata dan kaidah baku.

c) Jelas

Sebuah kalimat atau paragraf harus memiliki kejelasan atau dapat diterima nalar berpikir. Teks pidato 2 memuat beberapa kalimat atau paragraf yang kurang jelas karena beberapa hal. Hal yang dimaksud ialah kekeliruan memilih diksi sehingga terdapat makna ganda atau makna keliru yang membuat kalimat menjadi kurang jelas.

\section{d) Ringkas}

Sebuah kalimat dinyatakan efektif jika hemat dalam pemakaiannya. Kalimat yang hemat akan memudahkan komunikan menerima informasi yang disampaikan. Dalam teks pidato 2, terdapat beberapa kalimat yang tidak hemat sehingga membuat penerima informasi kesulitan untuk menangkap maksud penyampai informasi.

Bahkan sekarang ini, kita menjadi rujukan banyak negara dalam hal mengelola kebhinnekaan dan membangun persatuan.

(seharusnya kata ini dihapuskan karena sama-sama menunjukkan waktu sekarang)

e) Koherensi
Sebuah teks harus memiliki kepaduan antarkalimat atau antarparagraf sehingga dapat dikatakan efektif. Pada teks pidato 2 dijumpai ketidak paduan antarparagraf. Hal ini terlihat dari gagasan yang mendasarinya.

Kita harus ingat bahwa kita pernah menjadi tempat bagi negara lain untuk belajar, belajar tentang Islam, belajar tentang seni budaya, belajar tentang ilmu pengetahuan dan teknologi dan lain-lain. Kebanggaan inilah yang harus kita rebut kembali, kebanggaan terhadap kreasi dan karya sendiri, kebanggaan terhadap produk sendiri.

(tidak berkaitan dengan paragraf sebelumnya karena di paragraf sebelumnya membahas persatuan sedangkan di paragraf ini membahas tentang Pendidikan)

f) Tidak Sesuai

Pada teks pidato 2 dijumpai ketidaksesuaian dalam kalimat. Kalimat yang seharusnya aktif justru didalamnya terdapat kata yang membuatnya menjadi tidak sesuai.

\section{Pidato Kenegaraan Jokowi 3}

Berdasarkan data yang ditemukan di dalam naskah pidato Jokowi terdapat penggunaan kalimat yang tidak efektif, antara lain meliputi gramatikal, PUEBI, ringkas, dan bervariasi.

\section{a) Gramatikal}


Pertama, kesalahan yang dapat dikategorikan menyangkut gramatikal yang terkait dengan paragraf. Sebuah paragraf yang benar jika sebuah paragraf terdiri lebih dari satu kalimat.Kutipan Pidato Jokowi 3 menunjukkan paragraf yang tidak tepat:

Capaian-capaian tersebut menjadi pemicu bagi kita semua untuk terus bekerja keras bagi peningkatan kesejahteraan seluruh rakyat Indonesia.

(paragraf tidak boleh terdiri dari satu kalimat)

Kedua, kesalahan penulisan kata asing yang digunakan dalam teks pidato 3 . Setiap kata asing yang belum diserap harus ditulis miring atau garis bawah (apabila teks itu ditulis dengan gaya miring secara keseluruhan). Ketiga, kesalahan penulisan, baik imbuhan maupun partikel. Dalam pidato ini terdapat beberapa kesalahan.

b) PUEBI

Adapun kesalahan yang ditemukan dalam naskah pidato Jokowi 3 meliputi:Pertama, kesalahan yang berkaitan dengan PUEBI terdapat pada penggunaan kata tidak baku. Kedua, tidak menggunakan diksi yang tepat. Ketiga, tidak menggunakan diksi yang sesuai dengan tata bahasa.

c) Jelas

paragraf yang kurang jelas karena pemilihan diksi yang kurang tepat sehingga kalimatnya menjadi kurang jelas atau kurang bernalar.

d) Ringkas.

Dalam teks pidato 3, terdapat beberapa kalimat yang tidak hemat sehingga membuat penerima informasi kesulitan untuk menangkap maksud penyampai informasi.

e) Koherensi

Pada teks pidato 3 dijumpai ketidakpaduan antarparagraf. Hal ini terlihat dari gagasan yang mendasarinya.

f) Bervariasi

Dalam pidato 3, terdapat kalimat yang tidak bervariasi dalam hal pemilihan kata.

\section{Simpulan dan Saran}

\section{Simpulan}

Hasil penelitian ini menunjukkan hasil penggunaan kalimat efektif di dalam teks pidato kenegaraan Jokowi. Penggunaan kalimat efektif di dalam teks pidato kenegaraan Jokowi sudah cukup baik, tetapi masih banyak kalimat-kalimat didalam teks pidato kenegaraan tersebut yang kurang efektif. Sehubungan dengan penelitian diatas dapat diketahui sacara Bersama pula bahwa penggunaan kalimat efektif sangat berpengaruh terhadap berbagai hal yang berkaitan dengan karya tulis.

Kalimat efektif dapat dibagi menjadi dua berdasarkan penggunaannya 
yaitu kalimat efetif untuk berkomunikasi lisan dan tulis. Komunikasi tulis memberikan penekanan pada penggunaan kalimat yang sesuai dengan tata bahasa dan kaidah yang baik dan benar, sedangkam pada komunikasi lisan kalimat dikatakan efektif apabila pendengar mudah memahami apa yang disampaikan pembicara.

Penggunaan kalimat efektif semakin dianggap sepele ketika banyaknya karya-karya tulis yang bermunculan tanpa memperhatikan keefektipan sebuah kalimat tersebut,salah satu contoh yang didapat dalam pidato kenegaraan Jokowi banyaknya kalimat yang tidak efektif dapat membuktikan kurangnya pemahaman penulis dalam penggunaan kalimat efektif.

\section{Saran}

Berdasarkan penelitian diatas dapat disimpulkan bahwa penggunaan dan pemahaman kalimat efektif. Sangat penting dalam kegiatan menulis, oleh sebab itu, penelitian ini perlu dilanjutkan lagi kedalam bidang lain. Disamping itu, pembelajaran kalimat efektif di SMP/SMA perlu di tingkatkan dalam penulisan objeknya. Teks pidato ini sangat penting digunakan sebagai objek penelitian. Hal ini disebabkan pidato merupakan ungkapan pikiran yang perlu dipahami pembacanya dengan benar dan tepat.

\section{Daftar Pustaka}

A.Widyamartaya. 2003. Seni Menggayakan Kalimat. Yogyakarta : Kanisius (Anggota IKAPI).

Arifin, Zaenal. 1987. Cermat Berbahasa Indonesia. Jakarta: PT. Mediyatama Sarana Perkasa

Bagus, Putrayasa, Bagus Ida. 2014. Kalimat Efektif (Struktur). Bandung: PT Refika Aditama.

Hendrikus, Wuwur. 2011.Retorika terampil berpidato, berdiskusi, berargumentasi, dan bernegosiasi. Yogyakarta: Penerbit Kanisius.

Henry, Guntur. 2015. Prinsip-prinsip dasar sastra. Bandung: CV Angkasa.

Hidayat, Bambang. 2017. Peningkatan Kemampuan Menulis Teks Pidato dalam Pembelajaran Keterampilan Menulis Melalui Media Berbasis Audio. Jurnal Pembelajaran Bahasa dan Sastra Indonesia, Vol 7, No. 1, 2017.

Nurpadillah, Veni. 2017. Wacana Kepemimpinan Analisis Makna Konotasi dalam Teks Pidato Perdana Presiden Jokowi. Jurnal Jala bahasa, Online Vol 13, No 1 2017.

Parera, Jos. 1982. Belajar Mengemukakan Pendapat. Jakarta: Erlangga

Priyatni. Tri Endah. 2010. Membaca sastra dengan ancangan literasi kritis. Jakarta:PT Bumi Aksar.

Setiarini, Yuni. 2015. Jurnal penelitian tindakan kelas Vl. 16, No. 4, Agustus 2015 (57-61). 